\title{
Analysis of diodes used as precision power detectors above the square law region
}

\section{Guldbrandsen, Tom}

\section{Published in:}

Conference on Precision Electromagnetic Measurements

Link to article, DOI:

10.1109/CPEM.1990.109916

Publication date:

1990

Document Version

Publisher's PDF, also known as Version of record

Link back to DTU Orbit

Citation (APA):

Guldbrandsen, T. (1990). Analysis of diodes used as precision power detectors above the square law region. In Conference on Precision Electromagnetic Measurements (pp. 48-48). IEEE.

https://doi.org/10.1109/CPEM.1990.109916

\section{General rights}

Copyright and moral rights for the publications made accessible in the public portal are retained by the authors and/or other copyright owners and it is a condition of accessing publications that users recognise and abide by the legal requirements associated with these rights.

- Users may download and print one copy of any publication from the public portal for the purpose of private study or research.

- You may not further distribute the material or use it for any profit-making activity or commercial gain

- You may freely distribute the URL identifying the publication in the public portal 


\title{
ANALYSIS OF DIODES USED AS PRECISION POWER DETECTORS ABOVE THE SQUARE LAW REGION
}

\author{
Tom Guldbrandsen \\ Physics Laboratory III \\ The Technical University of Denmark \\ DK 2800 Lyngby Denmark
}

\begin{abstract}
The deviation from square law found in diode power detectors at moderate power levels has been modelled for a general case. By applying the model the deviation can be eliminated if an extra set of measurements is made in situ. The accuracy of diode power detectors can thus be improved considerably.
\end{abstract}

\section{Introduction}

Diode power detectors are often preferred to bolometers due to their low power requirements. For precision measurements the dynamic range is, however, severely limited. The maximum power is limited due to deviations from square law. The minimum power is limited by the noise level as expressed by the "Tangential Signal Sensitivity". The dynamic range is too small for precision measurements unless the error caused by the deviation from square law is reduced.

The deviation from square law can be modelled if, as often is the case, the RF-signal is terminated in a 50 ohms load in the detector mount and the small signal impedance of the diode is large compared with 50 ohms. An analysis of this case has been made by Cullen et. al. [1]. A disadvantage is that most of the power is lost in the 50 ohms load and not in the diode. The sensitivity is thus reduced.

\section{Theory}

In the present paper the deviation from square law has been calculated for a more general system consisting of a number of diode detectors connected to a common arbitrary linear passive network containing an approximately sinusoidal source. This situation covers the case of the six-port. The diodes are isolated from each other at DC. No assumption has been made about diode impedances so the diodes are interacting with the network as well as with each other at the fundamental frequency and at the harmonics.
General power series are used for currentvoltage and capacitance-voltage characteristics.

The problem is solved stepwise by means of a perturbation method. First the corresponding linear problem is solved by neglecting the non-linear terms in the power series. Next the non-linear terms are introduced and equations for the changes in diode voltages and currents are set up. The diode voltages and currents are considered in the frequency domain. It is shown that only $\mathrm{DC}$, the fundamental frequency and the second harmonic need to be taken into account in order to find the first two terms in the power series describing the detection law. Similarly only the first four terms of the power series for the diode current-voltage characteristic and the first three terms of the power series for the diode capacitance-voltage characteristic should be taken into account in order to treat the problem in a consistent way.

At microwave frequencies it is generally not possible to perform quantitative calculations of deviations from square law. The reason is that second harmonic signals play a significant role and the circuit parameters are rarely known at the second harmonic frequency. Instead the form of the model is found and the deviation from square law can then be found and corrected for, if an extra set of measurements are made in situ for each frequency and excitation condition.

It is shown that for precision measurements the maximum power level can be increased by about 18 $\mathrm{dB}$ by correcting for the deviation from square law. The dynamic range can thus be increased sufficiently in order to enable fast measurements to be made with an accuracy of $10^{-3} \mathrm{~dB}$.

\section{Reference}

[1] A. L. Cullen and T. Y. An. IEE PR.OC, Vol. 129, Pt. H, No. 4, pp. 191-198, August 1982. 